\title{
Characterization of Zirconia- Hydroxyapatite Nanocomposites for Orthopedic and Dental Applications
}

\author{
Israa Khahtan Sabree* ${ }^{* 1}$, Ola Saleh Mahdi ${ }^{2}$ \\ University of Babylon, College of Materials Engineering \\ *Corresponding Author E-mail: israaks@yahoo.com
}

\begin{abstract}
Zirconium oxide ceramic was proposed for different biomedical applications. It is used in orthopedic as hip and knee prostheses and in dentistry due to the good mechanical, biological high corrosion and wear resistance properties, addition to the aesthetic property owing to tooth like color. Zirconia stabilized with $\mathrm{Y}_{2} \mathrm{O}_{3}$ has the best properties for these applications. The present work aims to study the effect of (5 and 10)Wt.\% hydroxyapatite (HA) as additives to $3 \mathrm{~mol} \%$ yttria stabilized zirconia (3YSZ) nano powder matrix. The green body samples were shaped by powder technology using cold pressing then sintering at $(1300 \text { and } 1400)^{\circ} \mathrm{C}$. The 3 YSZ/ HA nanocomposites samples were characterized by XRD to investigate phase stability with varying percent's of HA and different sintering temperatures, the mechanical properties (maximum bending strength and hardness) were investigated as a function of the HA content, the changes of the thermal expansion coefficient for composite samples were investigated using Dilatometer. The experimental results proved that additions of (5 and 10)Wt.\% HA to 3 YSZ matrix reduce both hardness and max. bending strength, while increasing sintering temperature from $1300^{\circ} \mathrm{C}$ to $1400^{\circ} \mathrm{C}$ leading to an increase in the hardness and bending strength for all composite samples. The results of thermal expansion test showed a reduction in the thermal expansion coefficient with presence of HA\%, however the coefficient of $3 Y S Z /$ $10 \% \mathrm{HA}$ is closer to $3 \mathrm{YSZ}$ from $3 \mathrm{YSZ} / 5 \% \mathrm{HA}$. EDS analysis shows improvement in the bioactivity of inert $3 \mathrm{YSZ}$ with HA\% additions represented by increasing $\mathrm{Ca}$ and $\mathrm{P}$ ions on the composite samples after immersing in SBF for 6 days.
\end{abstract}

Keywords: Zirconia, Hydroxyapatite, nanocomposites, bioceramic, dentalbioceramics, orthopedic bioceramic.

\section{Introduction}

Zirconia-based ceramics have exceptional mechanical properties including (fracture toughness, strength and hardness), outstanding biocompatibility, aesthetics and heat conductivities that introduced it in dental and orthopedic applications over the last decades[1], however zirconia was classified as bioinert, which hampers their implantation in direct contact with bone. Furthermore, infections remain one of the leading causes of implant failure. There are three different pattern phases for Zirconia crystals: monoclinic $(\mathrm{m})$, tetragonal (t) and cubic (c). Phase transformations of $\mathrm{ZrO}_{2}$ associated with variation in crystal volume which produce internal stresses resulting early fracture during clinical applications [1]. When zirconia of monoclinic phase is heated, a transformation process to the tetragonal phase takes place at $1187{ }^{\circ} \mathrm{C}$, and finishes at $1206{ }^{\circ} \mathrm{C}$. During cooling stage, opposite transformation from the tetragonal to the monoclinic phase go on at $1052{ }^{\circ} \mathrm{C}$ and finishes at $1020{ }^{\circ} \mathrm{C}$, it's called martensitic transformation. The volume of monoclinic unit cell is $4 \%$ more than the volume of tetragonal unit cell, this leads to the creation of ceramic flaws if no stabilizing oxides were used [2], many researches focused on using 3YSZ for prosthodontic applications (e.g., crowns, implants)and orthopedic implants, because this material exhibit the best combination of strength, toughness and hardness [3, 4]. In dental tissue replacement, highstrength $3 \mathrm{YSZ}$ has been used for many purposes, as root canal posts, crowns for other ceramics, fixed and removable dental prostheses, implant supports, and dental fillers [5].
The strategy of improving biocompatibility of various strong materials involves the incorporation of bioactive materials like hydroxyapatite. Hydroxyapatite (HA) is biocompatible and osteoconductive, having chemical composition and structure similar to mineral phase of bone and tooth tissues, it shows chemical reactions resulting a direct bond with hard tissue and promotes the new formation of bone tissues. However the disadvantage of HA is the poor mechanical strength (brittleness and low fracture toughness) that leads to limited fitness in loadbearing applications [6,7].In most applications of biomedical materials the mechanical properties are especially important, as well as the chemical reactivity of their surfaces for this reasons using bioactive ceramic such as HA has attracted a great attention for enhancing the biocompatibility of many strong biomaterials through the use of composite or as coating layer to achieve osseo integration and accelerate new bone formation beside high strength which is required for load-bearing applications such as dental/orthopedic implants [8]. Therefore, 3YSZ and other strong ceramics are considered a suitable matrix material for the HAaddition to produce biocompatible and strong composites to be used in load-bearing parts [9], while other researchers used HA as coating layer on porous zirconia substrate for bone tissue engineering scaffold, to facilitate bone generation around zirconia scaffold [10].

The present study concentrated on studying the properties of 3 mol\% yttria stabilized zirconia (3YSZ) nano-powder through the addition of bioactive HA. The flexure strength, hardness, thermal expansion coefficient and XRD analysis were examined for the composites (3YSZ/ HA) samples as a function of the HA wt.\% content using $(1300,1400){ }^{\circ} \mathrm{C}$ as different sintering temperatures. 


\section{Materials and Methods}

\subsection{Production of Materials}

Commercially available 3YSZ nano powder (3YSZ, HWNANO, China) with particle size $(<100 \mathrm{~nm})$ and high purity (99.99\%).Prepared hydroxyapatite (HA) powder was used to produce composite samples. HA powder was prepared using simulated body fluid (SBF) solution and the raw materials are: Calcium nitrate tetra hydrate $\mathrm{Ca} \quad\left(\mathrm{NO}_{3}\right)_{2} \cdot 4 \mathrm{H}_{2} \mathrm{O} \quad(99 \%)$, Diammonium hydrogen phosphate $\left(\mathrm{NH}_{4}\right) 2 \mathrm{HPO}_{4}(99 \%)$ and $\mathrm{NH}_{4} \mathrm{OH}$ solution. The procedure of this method includes disbanding of $\left(\mathrm{NH}_{4}\right)_{2} \mathrm{HPO}_{4}$ and $\mathrm{Ca}\left(\mathrm{NO}_{3}\right)_{2} \cdot 4 \mathrm{H}_{2} \mathrm{O}$ in discrete beakers in SBF solution for experimenting precipitation as shown in Figure 1.When all reagents dissolved in SBF, direct fine precipitation created small turbidity in the solution, filtering this solution using filter paper with addition of distilled water after that the remainder was saved for a day in oven. Dried material was milled in a mortar to fine particles [11].To produce composite samples varying amounts of HA (5 and 10) wt $\%$ were blended in 3 YSZ powder. The mixed powder was ball-ground $3 \mathrm{~h}$ using a (SFM-1, QM-3SP2) planetary ball mill with rounds at $300 \mathrm{rpm}$ in acetone as a dispersive media, then cold pressedby uniaxial pressure device (CT340-CT440) using cylindrical dies of (13× 26) $\mathrm{mm}$ andrectangular dies of $(50 \times 8 \times 5) \mathrm{mm}$. All compacted samples were oven dried using electricblast dry box (WG43) at $100{ }^{\circ} \mathrm{C}$ for 24 hours. Firing process took place at two different temperatures $(1300$ and 1400$){ }^{\circ} \mathrm{C}$ for $2 \mathrm{~h}$ with a heating rate of 5 ${ }^{\circ} \mathrm{C} / \mathrm{min}$.

\section{Investigational procedures}

The documentation and the crystallite phases of the composite samples after firing were categorized by $\mathrm{x}$-raydiffractometer (Shimadzo, 6000) using Cuk $\alpha$ radiation $(\lambda=1.5405 \AA$ ), and 40 $\mathrm{KV} / 30 \mathrm{~mA}$ power applied.

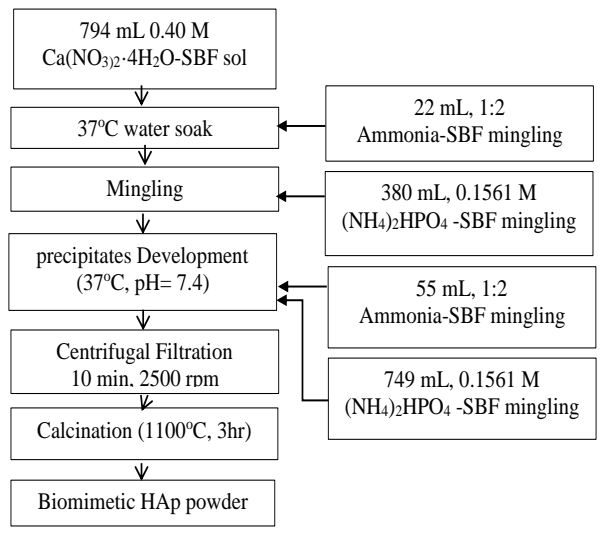

Fig. 1: Hydroxyapatite(HA) synthesis process

Analysis of particle size was extended using laser particle size analyzer (Bettersize2000). Thermal expansion curves were carried out to the sintered rectangular samples, the measurement of temperature range was $100-600{ }^{\circ} \mathrm{C}$ via differential dilatometer in helium atmosphere.Microhardnesshad been measured in accordance with ASTM C 1327-99 with indentation load of 9.8 N with a dwelling time of 15 second.Vickers hardness was deliberated by the following equation.

$\mathrm{Hv}=1.854(\mathrm{p} / \mathrm{d} 2)$

$\mathrm{Hv}$, the Vickers hardness (Mpa), p, load (N), D, diagonal length of the indentation impression $(\mu \mathrm{m})[12]$.
Three point bending was made according to ASTMC1161 procedure using computerized universal testing appliance with a speed test of $0.5 \mathrm{~mm} / \mathrm{min}$. The bending strength was calculated using the following equation.

$(\sigma b)=3 \mathrm{pfL} / 2 \mathrm{wt} 2$

Where $\sigma b$, is the bending strength (Mpa), pf, fracture load $(\mathrm{N}), \mathrm{w}$, width sample $(\mathrm{mm}), \mathrm{t}$, thickness sample $(\mathrm{mm})[13]$.Coefficient of thermal expansion (CTE) is important property in the field of esthetic restoration, where Zirconia used as a core covering by veneering ceramic, high difference in CTE between the cores and covering layer leads to a decrease in bond strength and produces clinical problems by chipping of veneering porcelain [14, 15].The coefficient of thermal expansion (CTE), $\alpha$, for composite samples was measured by (Quickline - 05) dilatometer affording the appearance below: $\alpha=1 / \mathrm{L}^{\circ} . \Delta \mathrm{L} / \Delta \mathrm{T} \ldots . .(3)$

Where, $\mathrm{L}^{\circ}$ : the length of sample at temperature of theambient, $\Delta \mathrm{L}$ : the increasing in length and $\Delta \mathrm{T}$ : is the temperature difference. The bioactivity test was investigated by submerging the samples in the simulated body fluid (SBF) which was prepared according to Kokubo protocol, 1990 [16], the test took place at $37{ }^{\circ} \mathrm{C}$ for six days. EDS analysis was carried out for samples surfaces at the end of immersion time to check the

Concentration of ( $\mathrm{Ca}$ and $\mathrm{P}$ ) ions and giving an indicator to $\mathrm{HA}$ formation .The change in solution $\mathrm{pH}$ was checked every day by $\mathrm{pH}$ meter mention to the variation of $(\mathrm{Ca}$ and $\mathrm{P})$ ions concentration in the solution during immersion time.

\section{Results and discussion}

\subsection{Phase Evaluation}

XRD patternof raw HA powder scanning of $5 \circ / \mathrm{min}$ from $5 \circ$ to $50^{\circ}$ of $2 \theta$, in the peak locations agrees to the HA phase when matching its peaks with ASTM card No. (09-0432), as shown in Figure 2.The prepared HA powder was calcined at $1100^{\circ} \mathrm{C}$ for 3 hours. The powder displays HA peaks similar in the circumstance of prepared HA as shown in Figure 3, Figure 4 and Figure 5 resume the XRD patterns for all sintered powders, Yttria stabilized Zirconia(3YSZ) and yttria stabilized Zirconia(3YSZ)with different weight percentages of hydroxyapatite (HA) (5 and 10) wt $\%$, scanned in diffraction angle (2Ө) from $10^{\circ}$ to $60^{\circ}$ upon heat treatment at $1300^{\circ} \mathrm{C}$ and $1400^{\circ} \mathrm{C}$. The figures indicate that $3 \mathrm{YSZ}$ appears as major phase and all peaks are related to it as compared with XRD standard card no. (48-0224). and HA as unique phases in the biocomposites. In all cases HA peaks were well recognized and increased with increasing weight percent without decomposition to TCP or reacting withYsZ during both sintering $(1300 \text { and } 1400)^{\circ} \mathrm{C}$, this result will serve in load-bearing applications because TCP is considered asbioresorbable material and dissolves faster than HA in body fluid .

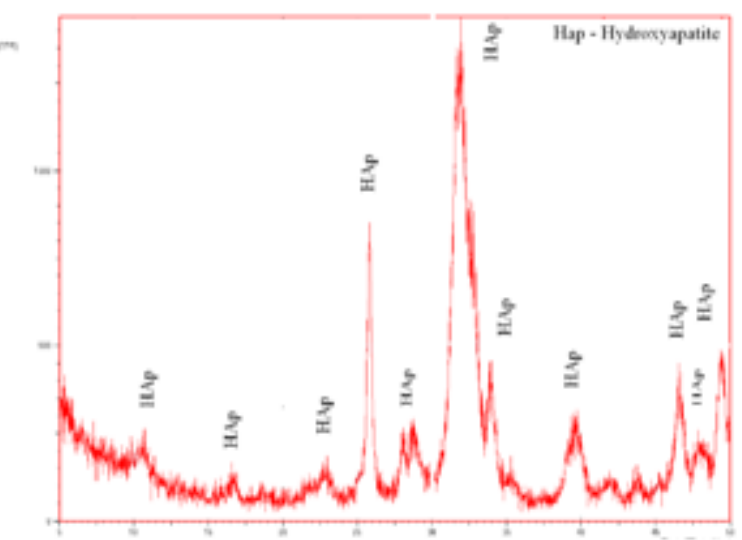

Fig. 2: XRD configuration of raw HA 


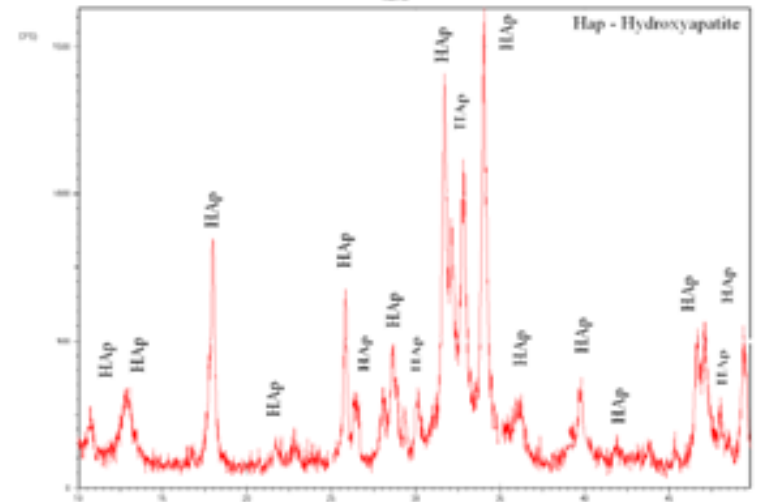

Fig. 3: XRD configuration of HA powder calcined at $1100 \circ \mathrm{oC}$.

\subsection{Particle Size Measurement}

Particle size of prepared HA was measured to provide about $4 \mu \mathrm{m}$ as normal particle size as exposed in Figure 6.

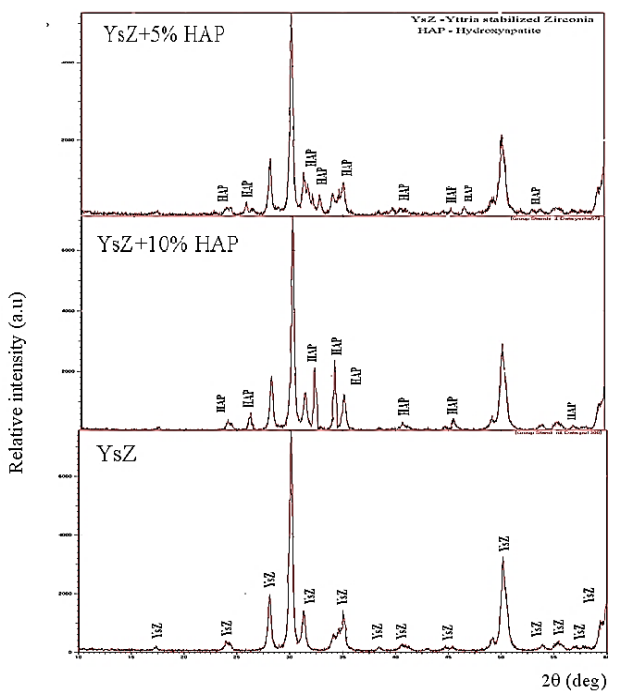

Fig. 4: XRD pattern of the $3 \mathrm{YSZ},(3 \mathrm{YSZ}+10 \% \mathrm{HA})$, and $(3 \mathrm{YSZ}+5 \% \mathrm{HA})$ sintered at $1300{ }^{\circ} \mathrm{C}$.

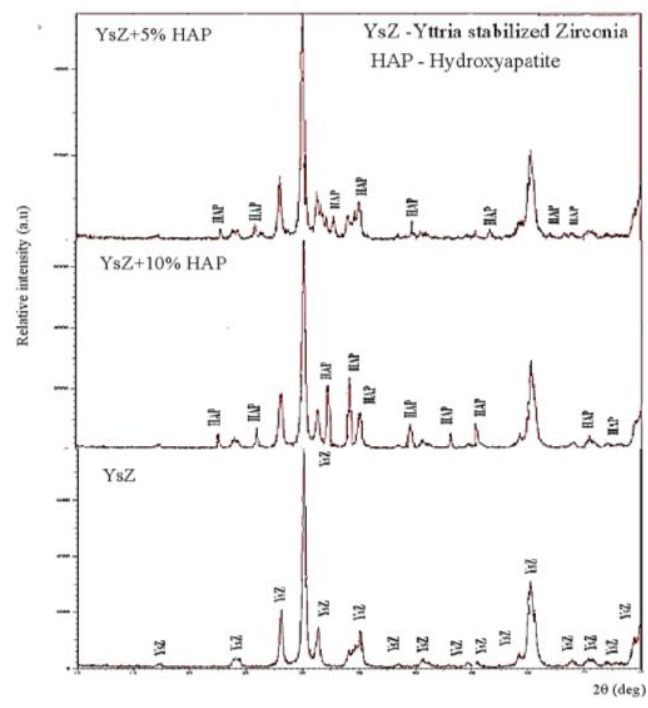

Fig. 5: XRD pattern of the $3 \mathrm{YSZ},(3 \mathrm{YSZ}+10 \% \mathrm{HA})$, and $(3 \mathrm{YSZ}+5 \%$ HA) sintered at $1400{ }^{\circ} \mathrm{C}$

\subsection{Mechanical Properties}

The Max. bending strength and hardness were evaluated for the prepared samples as shown in Figure 7 and Figure 8 respectively.
Bending strength for pure 3YSZ in both sintering temperatureshave been reported within the range of 900-1200 MPa [14], these values were decreased with increasing HA\% content. This may attributed to non-homogenous distribution and dispersion of large grains of HA in the 3 YSZ matrix resulting to weak regains of brittle HA, another reason may be the difference in thermal expansion coefficient between $\mathrm{HA}$ and 3YSZ matrixthat will produce stressed structure. The same above figures illustrate that using different sintering temperature $1300 \& 1400$ ${ }^{\circ} \mathrm{C}$ resulting a change in the mechanical properties for both pure and composite 3YSZ. The strength of the pure 3YSZ was increased from $1087 \mathrm{MPa}$ at $1300^{\circ} \mathrm{C}$ to $1101 \mathrm{MPa}$ at $1400^{\circ} \mathrm{C}$ sintering temperature. The same behavior was shown for composite samples with $(5 \& 10) \mathrm{Wt} . \% \mathrm{HA}$, the bending strength rises with increasing sintering temperature; the same scenario was repeated with hardness values were increasing HA\% reduces hardness of $3 \mathrm{YSZ}$, while increasing sintering temperature rising hardness . It is known that sintering procedure has an effect on the mechanical strength and microstructure of ceramic materials. This result was confirmed by Kong Y. et.al. 2005 [9], who added HA to $\mathrm{ZrO}_{2}-\mathrm{Al}_{2} \mathrm{O}_{3}$ nano-composite and got a reduction in mechanical properties. Figure 9 shows an increasing in shrinkage volume rate with increment of $\mathrm{HA} \%$, this comes in agreement with other research used bioglass as additive to 3YSZ [17] that may attributed to use different scale of particle size for HA and nano 3YSZ. At the same time it is clear that the higher sintering temperature $1400^{\circ} \mathrm{C}$ led tohigher volume shrinkage for pure and composite samples resulting from densification and a reduction in porosity leading to higher bending strength and hardness for all samples [18]. Figure10 shows that at the same sintering temperature HA additions led to slightly decrease in the thermal expansion coefficient of the composites compering with pure 3YSZ. Figure11 displays that the reduction in thermal expansion coefficient for composite samplestook place at both sintering temperature $(1300 \& 1400){ }^{\circ} \mathrm{C}$.It is well known that thermal expansion coefficient of $3 \mathrm{YSZ}$ is $11-12 \times 10^{-6}{ }^{\circ} \mathrm{C}^{-1}$ [19], after HA additions the difference in thermal expansion coefficient didn't exceed $(0.1-0.5) \times 10-6^{\circ} \mathrm{C}^{-1}$ for all temperatures, these differences may promote the generation of stress fields around the grains of 3 YSZ [17], wl 20(deg) : another reason for reduction in bending strength.

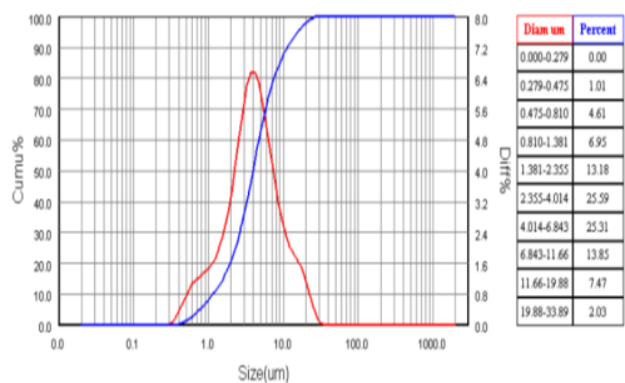

Fig. 6: Particle size analysis of the prepared HA powder.

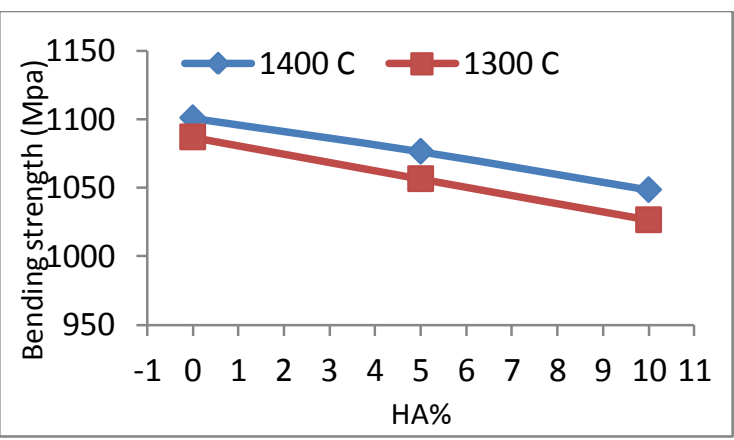

Fig.7: Variation the bending strength of $3 \mathrm{YSZ}$ with different percentages of HA 


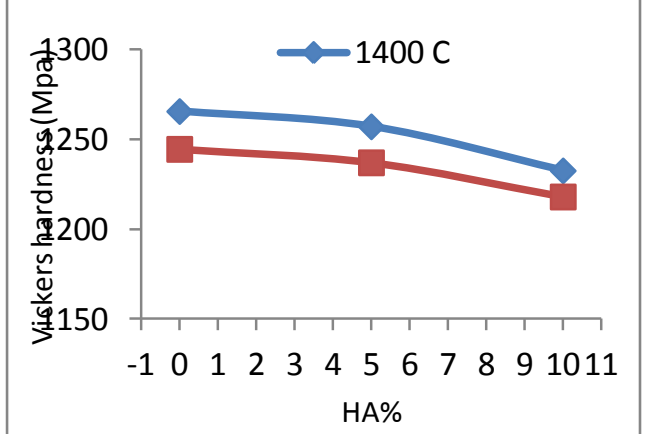

Fig. 8: Variation Vickers hardness of 3 YSZ with different percentages of HA

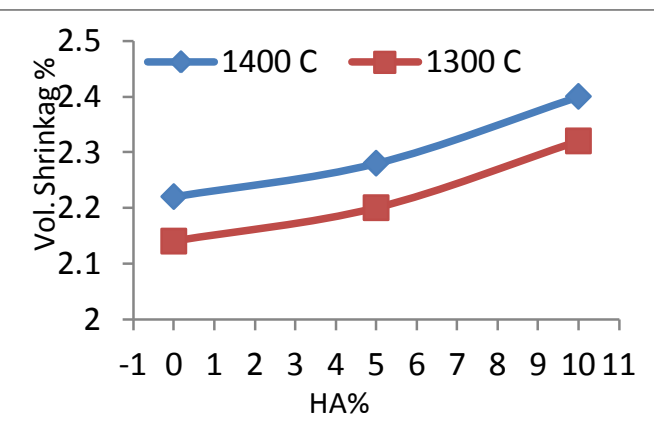

Fig. 9: Variation the shrinkage rate of $3 \mathrm{YSZ}$ with different percentages of HA

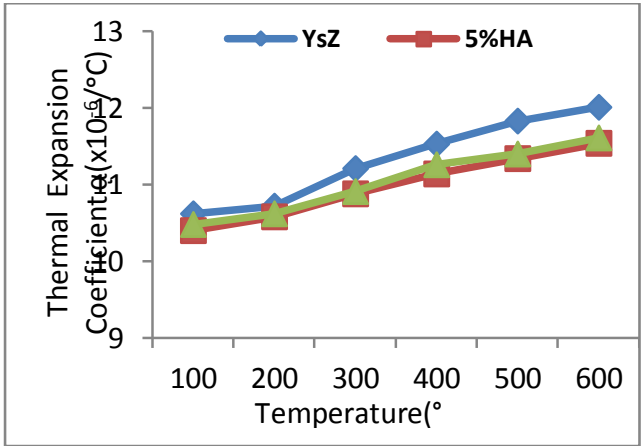

Fig. 10: Variation the thermal expansion coefficient of $3 \mathrm{YSZ}$ with different percentages of $\mathrm{HA}$ sintered at $1300^{\circ} \mathrm{C}$.

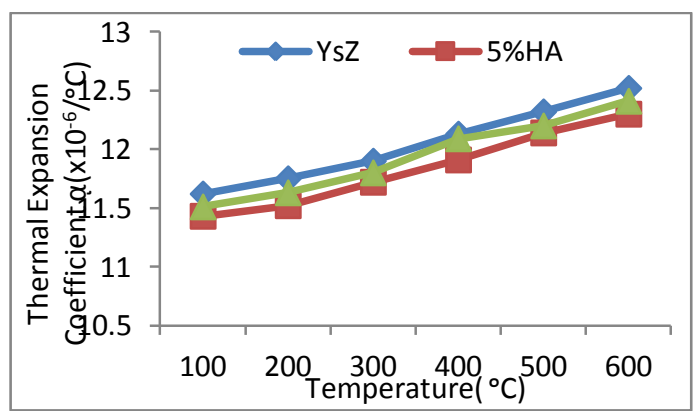

Fig. 11: Variation the thermal expansion coefficient of $3 \mathrm{YSZ}$ with different $\mathrm{HA} \%$ sintered at $1400^{\circ} \mathrm{C}$.

Figure 12 and Figure 13 illustrate that variation of $\mathrm{pH}$ in SBF started at the second immersion day for composite samples giving good indicator to HA role as active biomaterial in contrast with 3YSZ sample, were the $\mathrm{pH}$ stayed constant in all immersion days. We can observe that $\mathrm{pH}$ variation for composite samples sintered at $1300^{\circ} \mathrm{C}$ is more than samples sintered at $1400^{\circ} \mathrm{C}$, that may attributed to high densification at $1400{ }^{\circ} \mathrm{C}$ leading to high shrinkage and low porosity, all above produce samples with lower surface area leading to a reduction in reaction rate and $\mathrm{pH}$ variation. EDS results in figure 14 and figure 15illustrate that increasing $\mathrm{HA} \%$ in the composite samples led to an increase in the concentration of $\mathrm{Ca}$ and $\mathrm{P}$ ions on the sample surfaces when they immersed in SBF for 7 days, giving an indicator for HA precipitation and increasing bioactivity and ability to form bonding layer with host tissue. These results were confirmed by Kong Y. et.al. 2005 [9] who found that using HA as additive to 3YSZ matrix lead to improve the bioactivity and biocompatibility to the inert ceramic.

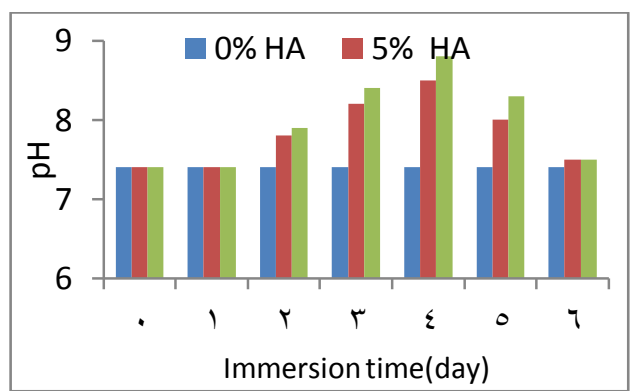

Fig. 12: Variation the $\mathrm{pH}$ of SBF for of $3 \mathrm{YSZ}$ with different percentages of HA sintered at $1300^{\circ} \mathrm{C}$.

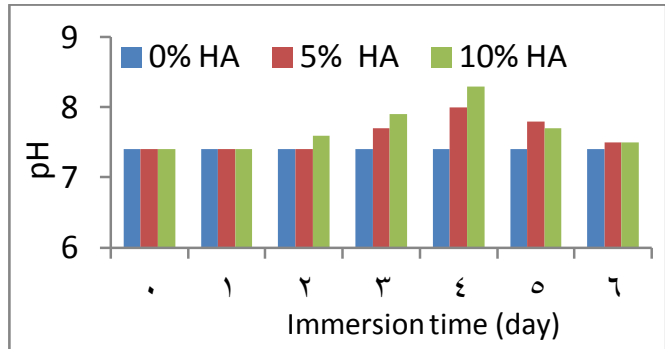

Fig. 13: Variation the $\mathrm{pH}$ of $\mathrm{SBF}$ for of $3 \mathrm{YSZ}$ with different percentages of HA sintered at $1400^{\circ} \mathrm{C}$

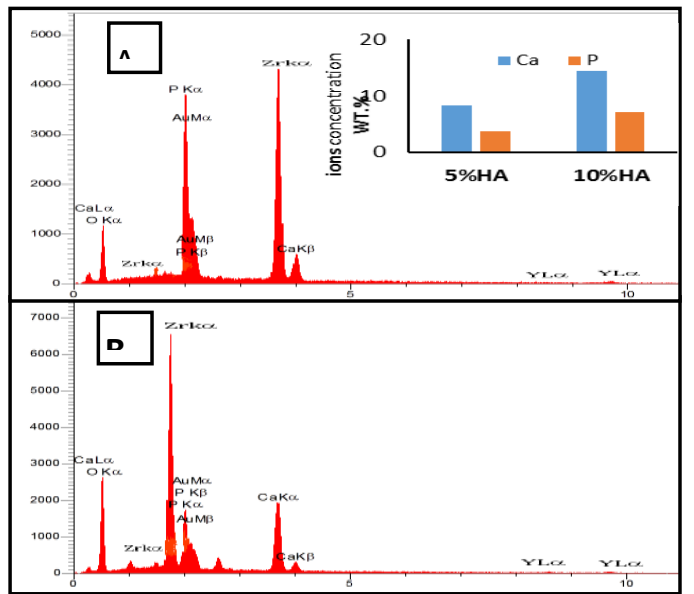

Fig. 14: EDS analysis for immersion surfaces of $3 \mathrm{YSZ}$ with A) $5 \%$ of $\mathrm{HA}$, B) $10 \%$ of $\mathrm{HA}$ sintered at $1300^{\circ} \mathrm{C}$

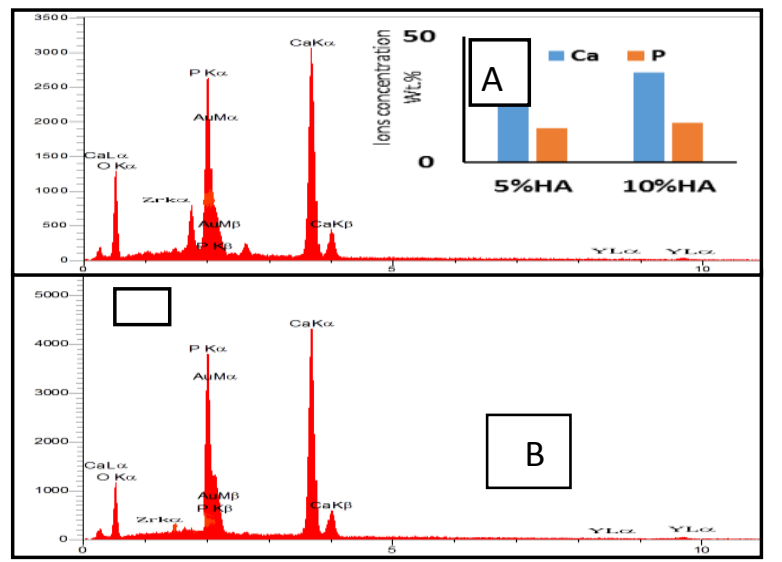

Fig. 15: EDS analysis for immersion surfaces of $3 \mathrm{YSZ}$ with A) $5 \%$ of HA, B) $10 \%$ of HA sintered at $1400^{\circ} \mathrm{C}$ 


\section{Conclusions}

The outcomes of this work demonstrates that the addition of $(5,10) \%$ HA to 3 YSZ matrix led to a reduction in the bending strength and vickers hardness. However, they are still more than that for cortical bone, also there is a slight decrease in thermal expansion coefficient for composite samples of 3YSZ / HA compering with pure 3 YSZ. In vitro, EDS result showed the ability of 3YSZ/ HA samples to form Ca-P-rich layer on the surface after immersing in SBF suggesting that the addition of HA led to form bonding layer with host tissue the property that is not found in pure 3YSZ. These results indicate that HA prepared by method used in this work may improve the bioactivity of new zirconia based composites. The next step of investigation should be the phase analysis of composites and description of the microstructure.

\section{References}

[1] Y.Ji1, X.D. Zhang, X.C.Wang, Z.C. Che, X.M. Yu and H.Z. Yang, Zirconia bioceramics as all-ceramics crowns material a review, Rev.Adv.Mater. Sci.Vol. 34(2),pp. 72-78,2013.

[2] A. D.Bona, O. E. Pecho and R.Alessandretti, Zirconia as a Dental Biomaterial, Materials, Vol. 8 (32),pp. 4978-4991, 2015.

[3] Q.Flamant, Surface modification of zirconia based bioceramics for orthopedic and dental applications, Doctoral thesis in Materials Science and Engineering UniversitatPolitècnica de Catalunya BarcelonaTech,2016.

[4] C.Vasconcelos, book sintering of ceramic, chapter: New Challenges in the Sintering of $\mathrm{HA} / \mathrm{ZrO}_{2}$ Composites, Centre of Physics and Technological Research Portugal, 2012.

[5] T.Tosiriwatanapong and W.Singhatanadgit, Zirconia-Based Biomaterials for Hard Tissue Reconstruction, Bone and Tissue Regeneration Insights, Vol. 9(12),pp. 1-9, 2018.

[6] C. H. Leong, A. Muchtar,C. Y. Tan, M. Razali, and N. F. Amat Sintering of Hydroxyapatite/Yttria Stabilized Zirconia Nanocomposites under Nitrogen Gas for Dental Materials, Hindawi Publishing Corporation, Advances in Materials Science and Engineering ,2014

[7] H.-W. Kim, Y.-J. Noh, Y.-H.Koh, H.-E. Kim, H.-M. Kim, Effect of $\mathrm{CaF}_{2}$ on densification and properties of hydroxyapatite-zirconia composites for biomedical applications, Biomaterials, Vol.5(16),pp.4113-4121,2002.

[8] Y. Harada, Experimental studies of healing process on compound blocks of hydroxyapatite particles and tricalcium phosphate powder implantation in rabbit mandible. J Tokyo Dent College Soc, Vol. 5(11),pp.89-97,1989.

[9] Y.-M. Kong, C.-J. Bae, S.-H. Lee, H.-W. Kim, and H.-E. Kim, Improvement in biocompatibility of $\mathrm{ZrO}_{2}-\mathrm{Al}_{2} \mathrm{O}_{3}$ nano-composite by addition of HA, Biomaterials, Vol. 1(3),pp. 509-517,2005.

[10] K.-S. Lew, R. Othman, K. Ishikawa and F.-Y.Yeoh, Macroporousbioceramics: A remarkable material for bone regeneration, Journal of Biomaterials Applications, Vol. 10,pp.,345-358,2016.

[11] A. Cuneyt Tas. Synthesis of Biomimetic Ca-hydroxyapatite powders at $37^{\circ} \mathrm{C}$ in synthetic body fluids, Biomaterials, pp. 1429 , 1438,2000

[12] M. A. Encinas-Romero, S. Aguayo-Salinas, J. L. Valen- zuelaGarcía, S. R. Payán and F. F. Castillón-Barraza, Mechanical and Bioactive Behavior of Hydroxyapatite- Wollastonite Sintered Composites, International Journal of Applied Ceramic Technology, Vol. 7, (. 2), pp. 164-167,2010.

[13] S. M. Best, A. E. Porter, E. S. Thian and J. Huang, Bio- ceramics: Past, Present and for the Future, Journal of the European Ceramic Society, Vol. 28, ( 7), pp. 1319-1327,2008

[14] O. S.Abd El-Ghany, A. H.Sherief, Zirconia based ceramics, some clinical and biological aspects: Review, Future Dental Journal Vol. 2,pp., 55-64,2016

[15] U.Alsulami, A.Alshihri, W.Huraib, T.Alzahrani, H.Albakkar, The Effect of Coefficient of Thermal Expansion Differences on Bond Strength of Ceramic-Zirconia Interface, IntJ Dent Med Res, Vol ( 6), 2015 .

[16] T. Kokubo, H. Kushitani, S. Sakka, T. Kitsugi and T. Yamamuro, Solutions able to reproduce in vivo surface-structure changes in bioactive glass-ceramic A-W, J. Biomed. Mater. Res., Vol. 24(2),pp. 721-734,1990.

[17] L. A. Bicalho, C. A. R. P. Baptista, M. J. R. Barboza, C. Santos and R. C. Souza, $\mathrm{ZrO}_{2}$-Bioglass Dental Ceramics: Processing ‘Structural and Mechanics Characterization, Advances in Ceramics -Electric and Magnetic Ceramics, Bioceramics, Ceramics and Environment.

[18] M.N.Rahaman, Ceramic processing and sintering, book, $2^{\text {nd }}$ edition, 1997.

[19] I. C. Clarke, G.Pezzotti and N. Sugano, Materials in Hip Surgery: Mechanical Properties That Influence Design and Performance of Ceramic Hip Bearings, Chapter 7, 2016. 